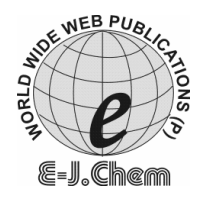

http://www.e-journals.net
ISSN: 0973-4945; CODEN ECJHAO

E-Journal of Chemistry $2009, \mathbf{6}(2), 469-474$

\title{
Development and Validation of RP-HPLC Method for the Determination of Adefovir Dipivoxil in Bulk and in Pharmaceutical Formulation
}

\author{
ZAHEER AHMED, B. GOPINATH*, \\ A. SATHISH KUMAR SHETTY and B. K. SRIDHAR \\ Department of Pharmaceutical Analysis, \\ National College of Pharmacy, Shimoga-577201, (K.S.), India. \\ zaheer_ahmed@rocketmail.com
}

Received 15 September 2008; Accepted 1 November 2008

\begin{abstract}
A rapid and sensitive RP-HPLC method with UV detection (262 nm) for routine analysis of adefovir dipivoxil in bulk and in pharmaceutical formulation was developed. Chromatography was performed with mobile phase containing a mixture of acetonitrile and phosphate buffer $(50: 50, \mathrm{v} / \mathrm{v})$ with flow rate $1.0 \mathrm{~mL} \mathrm{~min}{ }^{-1}$. In the range of $5.0-100 \mu \mathrm{g} / \mathrm{mL}$, the linearity of adefovir dipivoxil shows a correlation co-efficient of 0.9999 . The proposed method was validated by determining sensitivity accuracy, precision, robustness stability, specificity, selectivity and system suitability parameters.
\end{abstract}

Keywords: Adefovir dipivoxil, RP-HPLC, Validation.

\section{Introduction}

Chemically, adefovir dipivoxil (bis(POM)-PMEA), known as 9-[2-(\{bis[(pivalaloyloxy) methoxy] phosphinyl] $\}$ methoxy) ethyl] adenine ${ }^{1,2}$.(Figure 1). Adefovir dipivoxil is a diester prodrug of the active moiety adefovir, it is an acyclic nucleotide analogue of adenosine monophosphate ${ }^{3}$. It is a novel antiviral drug, which is highly efficient in the treatment of human hepatitis B virus (HBV) and HIV. It was reported that adefovir dipivoxil dose at 10 $\mathrm{mg}$, once daily taken orally in the treatment of chronic hepatitis in adults with evidence of active viral replication and either evidence of persistent elevations in serum aminotransferases (ALT or AST) or histologically active disease. Adefovir is phosphorylated to the active metabolite, adefovir diphosphate, by cellular kinases, adefovir diphosphate inhibits HBV DNA polymerases ${ }^{4}$ (reverse transcriptase) by competing with the natural substrate deoxyadenosine triphosphate and by causing DNA chain termination after its incorporation into viral DNA. Adefovir dipivoxil is absorbed rapidly \& extensively after oral administration, and approximate oral bioavailability of adefovir from adefovir dipivoxil is $59 \%{ }^{5}$. In vitro binding of adefovir to human plasma or human serum proteins is $4 \%$ over 
the adefovir concentration range of 0.1 to $25 \mathrm{mg} / \mathrm{mL}$. Metabolism involves the rapid conversion of adefovir dipivoxil to adefovir, $45 \%$ of the dose . Adefovir is renally excreted by a combination of glomerular filteration \& active tubular secretion ${ }^{6}$. Since, adefovir dipivoxil is widely used in the antiviral therapy, it is important to develop and validate analytical methods for its determination in pharmaceutical dosage form. The present work reports the development and validation of a RPHPLC method for the estimation of adefovir dipivoxil in bulk and in tablets, So for no systematic RP-HPLC method has been reported, however only a few bio-analytical methods were reported using human plasma by LCMS/MS ${ }^{7,8}$. The present work reports a rapid and sensitive RP-HPLC determination method with UV detection, useful for routine quality control of adefovir dipivoxil in bulk and in pharmaceutical formulations. The method was validated by parameters such as linearity, accuracy, precision, robustness, stability and system suitability.

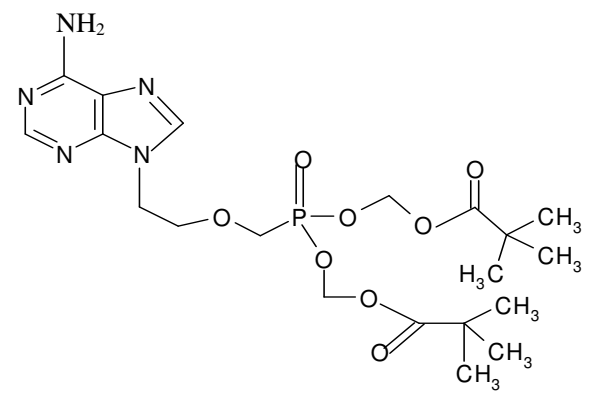

\section{Experimental}

Figure 1. Structure of adefovir dipivoxil.

HPLC system is used for this study, the specifications are given below. Quantitative HPLC was performed on a isocratic high pressure liquid chromatography (shimadzu HPLC class VP-Series) with one LC-10 AT VP pump, with UV/VIS detector SPD-10A VP, CTO-10 AS VP column oven (shimadzu),SCL-10A VP system controller (shimadzu), a disposable guard column LC-18 (PELLIGUARD) $^{\mathrm{TM}}$, LC-18, $2 \mathrm{~cm}$, supelco, inc., Bellefonte, and a Reverse Phase C-18 Column (150mm $\times 4.6 \mathrm{~mm}$ i.d.,particle size $5 \mu \mathrm{m}$ ) was used. The HPLC system was equipped with the software class, N-2000 CHROMTECK (Shimadzu).

\section{Reagents and chemicals}

HPLC grade methanol, acetonitrile, and potassium dihydrogen orthophosphate, sodium hydroxide (A.R. grade) was obtained from Qualigen (Mumbai, India). Pure sample of drug and the commercial formulation (Adesera-10 mg tablets) were obtained from Cipla laboratories Ltd Goa, India and (Adfovir - $10 \mathrm{mg}$ tablets) from Sun Pharmaceutical Ltd Baroda, India respectively. Triple distilled water obtained using a milli- ${ }^{\circledR}$ UF-PLUS apparatus (milli pore) was used to prepare all solutions for the method.

\section{Preparation of buffer}

$(0.05 \mathrm{M}) \mathrm{KH}_{2} \mathrm{PO}_{4}$ Buffer was prepared by dissolving $6.8 \mathrm{~g}$ of potassium dihydrogen ortho phosphate in $1000 \mathrm{~mL}$ of milli-Q water and the $\mathrm{pH}$ was adjusted to 6.0 with $10 \% \mathrm{NaOH}$.

\section{Preparation of standard stock solution of adefovir dipivoxil}

\section{Procedure}

About $100 \mathrm{mg}$ of adefovir dipivoxil was accurately weighed and transferred to a $100 \mathrm{~mL}$ volumetric flask. It was dissolved in $10 \mathrm{~mL}$ of methanol and made up to the volume with 
phosphate buffer of $\mathrm{pH}(6.0)$ and sonicated for $10 \mathrm{~min}$. From this, a working standard solution of $500 \mu \mathrm{g} / \mathrm{mL}$ of strength was prepared, from this dilution of $5,25,50,75, \& 100 \mu \mathrm{g} / \mathrm{mL}$ were made in $100 \mathrm{~mL}$ volumetric flasks \& make up with phosphate buffer of $\mathrm{pH}$ (6.0) $20 \mu \mathrm{L}$ of each dilutions was injected each time into the column at a flow rate of $1 \mathrm{~mL} / \mathrm{min}$. Each dilution was injected 3 times into the column and the corresponding chromatograms were obtained.

\section{Assay of adefovir dipivoxil in tablets}

Twenty tablets were weighed and finely powdered. An accurately weighed portion of the powder equivalent to $100 \mathrm{mg}$ of adefovir dipivoxil was transferred to $100 \mathrm{~mL}$ volumetric flask containing $10 \mathrm{~mL}$ of methanol and the contents of the flask were sonicated for $15 \mathrm{~min}$, to ensure the complete solubility of the drug. The mixture was then made up to $100 \mathrm{~mL}$ with phosphate buffer of $\mathrm{pH}(6.0)$.

The resulting solution was thoroughly mixed and filtered through a $0.45 \mu \mathrm{m}$ membrane filter. $5 \mathrm{~mL}$ of this solution was added to $100 \mathrm{~mL}$ volumetric flask and made up to the mark with phosphate buffer of $\mathrm{pH}(6.0)$. This solution $(20 \mu \mathrm{L})$ was injected three times into the column. The mean values of peak areas of five such determinations were calculated and the drug content in the tablets was quantified using the regression equation.

\section{Chromatographic conditions}

The content of the mobile phase were phosphate buffer solution (pH-6.0) and acetonitrile in the ratio of 50:50 percent $(\mathrm{v} / \mathrm{v})$. The contents of mobile phase were filtered before use through $0.45 \mu \mathrm{m}$ membrane filter and sonicated for $15 \mathrm{~min}$. The flow rate of the mobile phase was maintained at $1.0 \mathrm{~mL} / \mathrm{min}$. The column temperature was set at $25 \pm 1^{\circ} \mathrm{C}$ and the detection was carried out by UV-Detector wave length was set at $262 \mathrm{~nm}$. The run time was set at $10 \mathrm{~min}$ and the volume of the injection loop was $20 \mu \mathrm{L}$. Prior to injection of the drug solution, the column was equilibrated for at least $30 \mathrm{~min}$ with the mobile phase flowing through the system. The data were acquired, stored and analysed with the software class N2000 CHROMTECK (SHIMADZU).

\section{Calibration procedure}

The calibration curve was plotted with five concentrations of the standard drug solution 5.0-100 $\mu \mathrm{g} / \mathrm{mL}$ solution and chromatography was repeated thrice for each dilution. The linearity was evaluated by linear regression analysis, before injecting solutions; the column was equilibrated for at least $30 \mathrm{~min}$ with the mobile phase flowing through the system five determinations were carried out for each solution, peak area ratios were recorded for all the solutions. The correlation graph was constructed by plotting the peak area ratios obtained at the optimum wave length of detection versus the injected amounts of the respective concentrations.

\section{Results and Discussion}

The applied chromatographic conditions permitted a good resolution of adefovir dipivoxil $(50 \mu \mathrm{g} / \mathrm{mL}$ ) in sample solution (A) and in standard solution (B) (Figure 2). No drug decomposition was observed during the analysis. The LC method was validated for the parameters reported below.

\section{Linearity}

The adefovir dipivoxil were chromatographed using the mobile phase, the linearity of peak area responses versus concentrations was studied from $5.0-100 \mu \mathrm{g} / \mathrm{mL}$ for adefovir dipivoxil. A linear response was observed over the examined concentration range. The results are tabulated in the Table 1. 


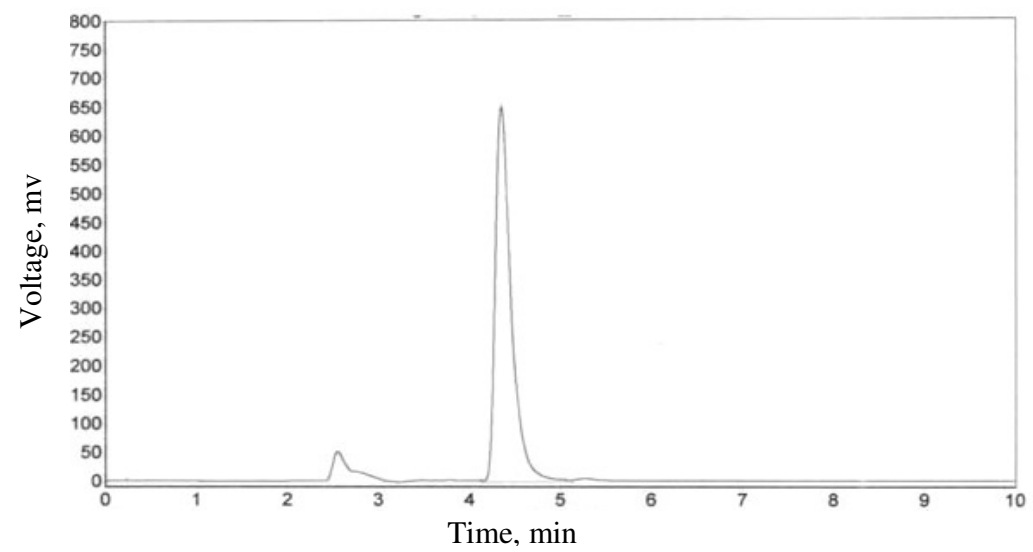

Figure 2. (A) Adefovir_dipivoxil - R.T: 4.357.

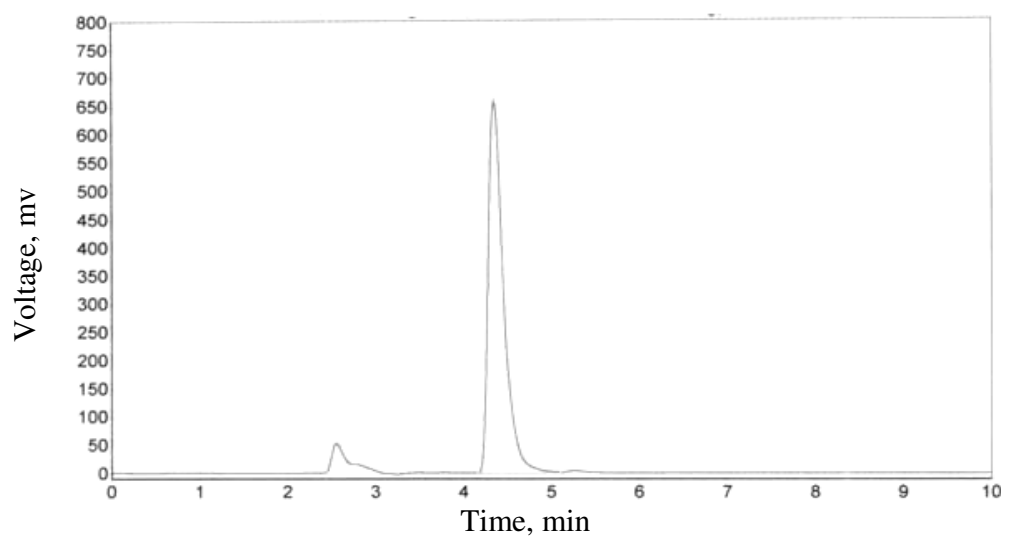

Figure 2. (B) Adefovir_dipivoxil -R.T: 4.357.

Table 1. Results of the data analysis for the quantitative determination of adefovir dipivoxil by the proposed method.

\begin{tabular}{lc}
\hline \multicolumn{1}{c}{ Statistical parameters } & HPLC \\
\hline Concentration range, $\mu \mathrm{g} / \mathrm{mL}$ & $5.0-100$ \\
Regression equation & $\mathrm{Y}=-329.03+194.07 \mathrm{X}$ \\
Correlation co-efficient (r) & 0.9999 \\
Limit of detection (LOD), $\mu \mathrm{g} / \mathrm{mL}$ & 0.4 \\
Limit of quantification (LOQ), $\mu \mathrm{g} / \mathrm{mL}$ & 1.0 \\
\hline
\end{tabular}

\section{Accuracy}

The accuracy of the HPLC assay method was assessed by adding known amount ( $25 \mu \mathrm{g}$ or 50 $\mu \mathrm{g})$ of the drug to a drug solution of known concentration $(50 \mu \mathrm{g} / \mathrm{mL})$ and subjecting the samples to the proposed HPLC method the known amount of drug solution $(25$ or $50 \mu \mathrm{g} / \mathrm{mL})$ was also added to the volumetric flask containing the powder sample of the tablet formulation with known amount of drug. The drug was estimated as the procedure described above for the estimation of adefovir dipivoxil in the tablet formulations. In both the cases the recovery studies were replicated five times. The accuracy was expressed in terms of the recovery and calculated by multiplying the ratio of measured drug concentration with 100 , so as to give the percent recovery. 
Table 2. Recovery of adefovir dipivoxil using proposed RP-HPLC method.

\begin{tabular}{ccc}
\hline $\begin{array}{c}\text { Amount of drug } \\
\text { added, } \mu \mathrm{g}\end{array}$ & $\begin{array}{c}\text { Mean }( \pm \mathrm{SD}) \text { amount } \\
\text { found, } \mu \mathrm{g}, \mathrm{n}=5\end{array}$ & $\begin{array}{c}\text { Mean }( \pm \mathrm{SD}) \% \text { of } \\
\text { recovery, } \mathrm{n}=5\end{array}$ \\
\hline 25 & $25.03 \pm 0.06$ & $100.12 \pm 0.03$ \\
50 & $49.61 \pm 0.08$ & $99.22 \pm 1.20$ \\
\hline
\end{tabular}

\section{Precision}

The precision of the assay was determined in terms of intra and inter day variation in the peak area for a set of drug solution $(25$ or $50 \mu \mathrm{g} / \mathrm{mL})$ assayed five times on the same day and on three different days. The intra and interday variation in the peak ratio of the drug solution was calculated in terms of co-efficient of variation $(\mathrm{CV})$ and obtained by multiplying the ratio of standard deviation to the mean with $100(\mathrm{CV}=\mathrm{SD} / \mathrm{MEAN} \mathrm{X} 100)$

Table 3. Inter and intraday precision for adefovir dipivoxil assay in pharmaceutical dosage forms by the proposed RP-HPLC method.

\begin{tabular}{ccccc}
\hline $\begin{array}{c}\text { Adefovir dipivoxil } \\
\text { concentration, } \mu \mathrm{g} / \mathrm{mL}\end{array}$ & \multicolumn{4}{c}{$\begin{array}{c}\text { Concentration of } \\
\text { adefovir dipivoxil }(\mu \mathrm{g} / \mathrm{mL}) \text { found on }\end{array}$} \\
\hline & \multicolumn{3}{c}{ Intraday } & \multicolumn{3}{c}{ Interday } \\
\cline { 2 - 5 } & Mean, $\mathrm{n}=5$ & $\mathrm{CV} \%$ & Mean, $\mathrm{n}=5$ & $\mathrm{CV} \%$ \\
\hline 50 & 25.02 & 1.34 & 24.32 & 0.92 \\
50 & 49.83 & 1.98 & 50.12 & 1.25 \\
\hline
\end{tabular}

\section{Robustness}

As defined by the ICH, the robustness of an analytical procedure describes to its capability to remain unaffected by small and deliberate variations in method parameters ${ }^{9,10}$. Robustness was performed by small variation in the chromatographic conditions and found to be unaffected by small variations like $\pm 2 \%$ variation in volume of mobile phase composition, $\pm 0.1 \mathrm{~mL} / \mathrm{min}$ in flow rate of mobile phase, \pm 0.1 variation in $\mathrm{pH}$

\section{Limit of detection and limit of quantization}

The parameters LOD and LOQ were determined on the basis of signal to noise ratio, LOD \& LOQ was calculated by the method which was based on the standard deviation (S.D.) of the response and the slope (S) of the calibration curve at levels approximating the LOD \& LOQ and was found to be 0.4 and $1.0 \mu \mathrm{g} / \mathrm{mL}$ respectively.

\section{Stability}

Results obtained in the study of the solution (both sample \& standard solution) where it can be noticed that the solutions were stable for $72 \mathrm{~h}$, as during this time the results does not decrease below the minimum percentage $(98 \%)$. Photo stability studies were also performed and showed that the active substance is not light sensitive.

Table 4. Mean ( \pm s.d.) amount of adefovir dipivoxil in tablet dosage forms by proposed RPHPLC method.

\begin{tabular}{cccc}
\hline Tablets* & $\begin{array}{c}\text { Labeled amount } \\
\text { of drug, mg }\end{array}$ & $\begin{array}{c}\text { Mean }( \pm \text { SD) amount } \\
\text { found, } \mathrm{mg}(\mathrm{n}=5)\end{array}$ & $\begin{array}{c}\text { Percentage } \\
\text { purity }\end{array}$ \\
\hline $\mathrm{T}_{1}$ & 10 & $9.76 \pm 0.03$ & 97.66 \\
$\mathrm{~T}_{2}$ & 10 & $9.85 \pm 0.04$ & 8.50 \\
\hline
\end{tabular}

$* \mathrm{~T}_{1}=$ Adfovir (Sun Pharmaceuticals), $\mathrm{T}_{2}=$ Adesera, (Cipla, Pharmaceuticals) tablets are obtained from different manufacturers. The absence of additional peaks indicates no interference 
of the excipients used in the tablet. The tablets was found to contain 97.66- $98.50 \%$ of the labeled amount.

\section{Specificity and selectivity}

Specificity and Selectivity where studied for the examination of the presence of interfering endogenous components, working solution containing adefovir dipivoxil was prepared with methanol \& phosphate buffer and mobile phase as a diluents, results indicate that the Retention time of adefovir dipivoxil is at $4.357 \mathrm{~min}$ respectively. None of the impurities were interfering in the assay.

\section{Conclusions}

The proposed reverse phase high performance liquid chromatographic method has been evaluated over the linearity, precision, accuracy, stability, specificity and proved to be convenient and effective for the quality control of adefovir dipivoxil in given application. The measured signal was shown to be precise, accurate, and linear over the concentration range tested $(5.0-100 \mu \mathrm{g} / \mathrm{mL})$ with a correlation coefficient of 0.9999 .

Thus the proposed method is rapid, selective, requires a simple sample preparation procedure, Moreover, the lower solvent consumption leads to a cost effective and represents a good procedure of adefovir dipivoxil determination in bulk \& in pharmaceutical dosage forms.

\section{Acknowledgment}

The authors are grateful to the Principal Dr. B. K. Sridhar, National College of Pharmacy, Shimoga for his support \& encouragement and for providing research facilities, authors are also thankful to the National Education Society, Shimoga.

\section{References}

1. O' Neil M J. The Merck Index - an encyclopedia of chemicals, drugs and biologicals, $13^{\text {th }}$ Ed., New Jersy, Merk \& Co., Inc., 2001.

2. Sweetmann S C. Martindale-The complete drug reference, $33^{\text {rd }}$ Ed., Pharmaceutical press, London (UK), 2002.

3. Hadziyannis S J, Tassopoulos N C, Heathcote E J, Chang T T, Kitis G and Rizzetto M, N Engl J Med., 2003, 27:348(9), 848-850.

4. Vere Hodge R A and Cheng Y C, Antivir Chem Chemother., 1993, 4 (Suppl.1), 13-24.

5. Pue M A and Benet L Z, Antivir ChemChemother., 1993, 4(Suppl.1), 47-55.

6. Murray A B, Antivir Chem Chemother.,1995, 6, 34-38.

7. Sparidans R W, Veldkamp A Hoetelmans R M and Beijenen J H, J Chromatogr. B. 1999, 736.

8. Vela J E, Olson L Y, Huang A, Fridland A and Ray A S, J Chromatogr B Analyt Technol Biomed Life Sci., 2007, 848(2), 335-343.

9. Topic Q2B, Validation of Analytical Methods: Methodology. The Third International Conference on Harmonization of Technical Requirements for Registration of Pharmaceuticals for Human Use,International Conference on Harmonisation,(ICH) Yokohama, Japan,1997.

10. Vander Heyden Y, Nijhuis A, Smeyers-Verbeke J, Vandeginste B G M, J Pharm Biomed Anal., 2001, 24 723-753. 


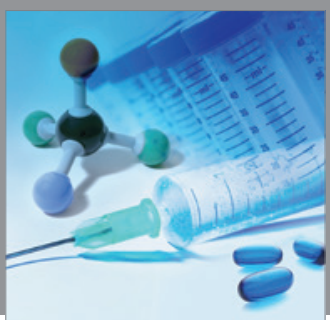

International Journal of

Medicinal Chemistry

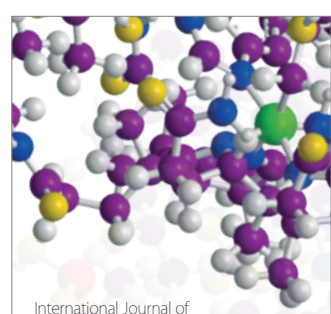

Carbohydrate Chemistry

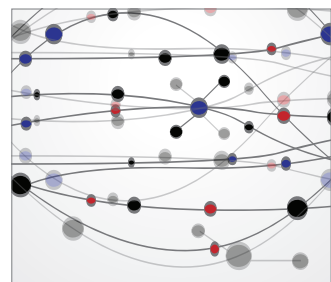

The Scientific World Journal
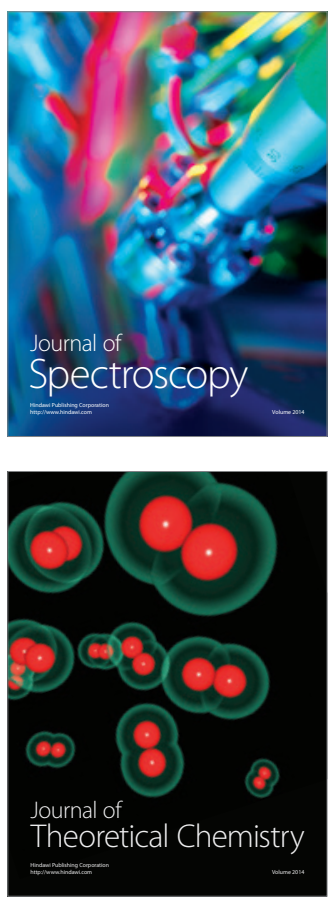
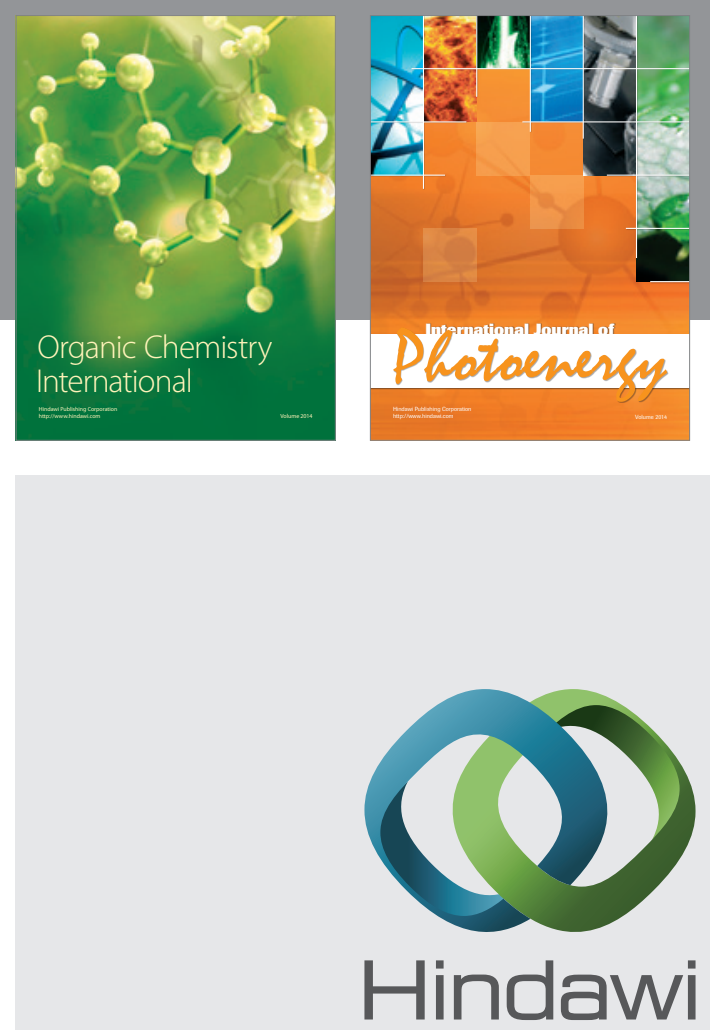

Submit your manuscripts at

http://www.hindawi.com
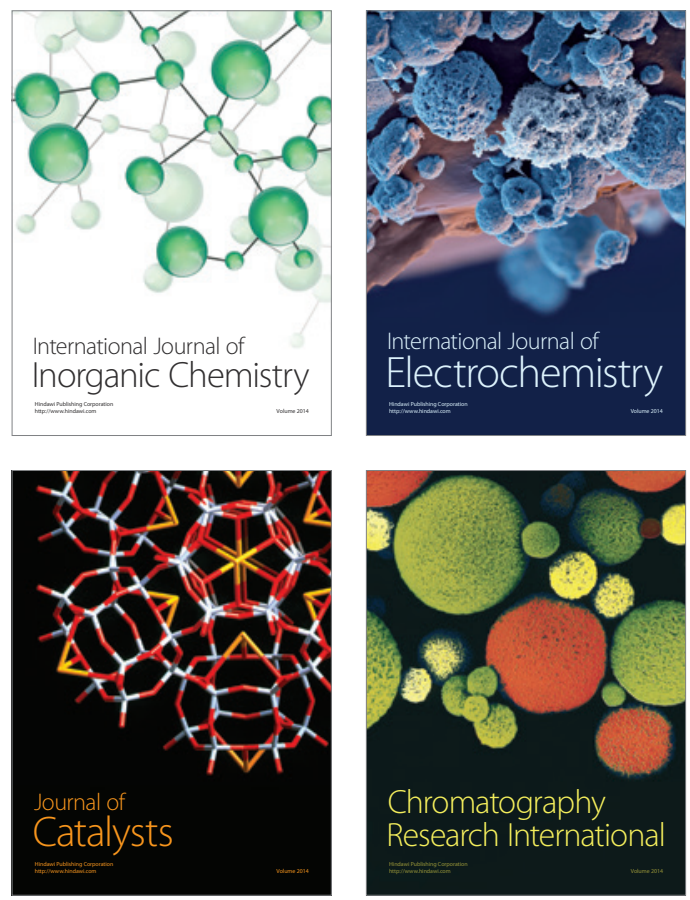
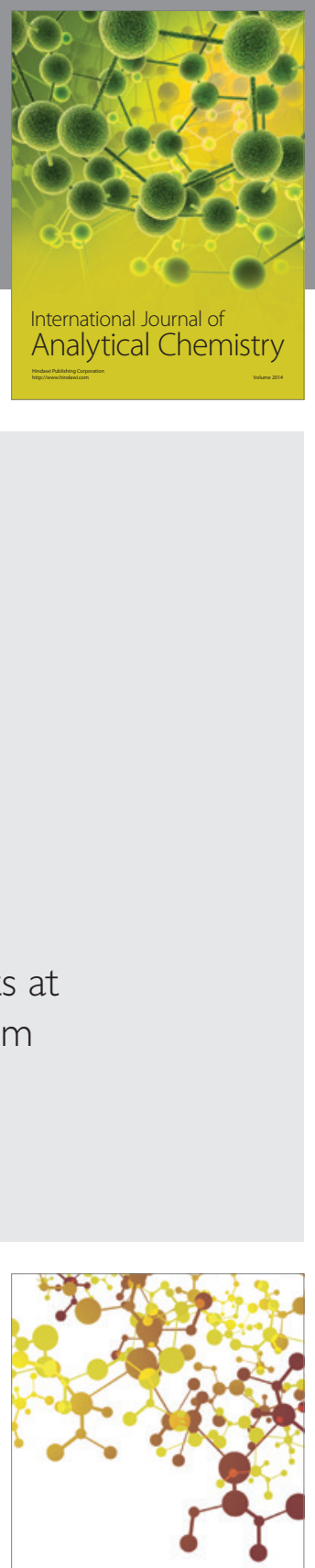

Journal of

Applied Chemistry
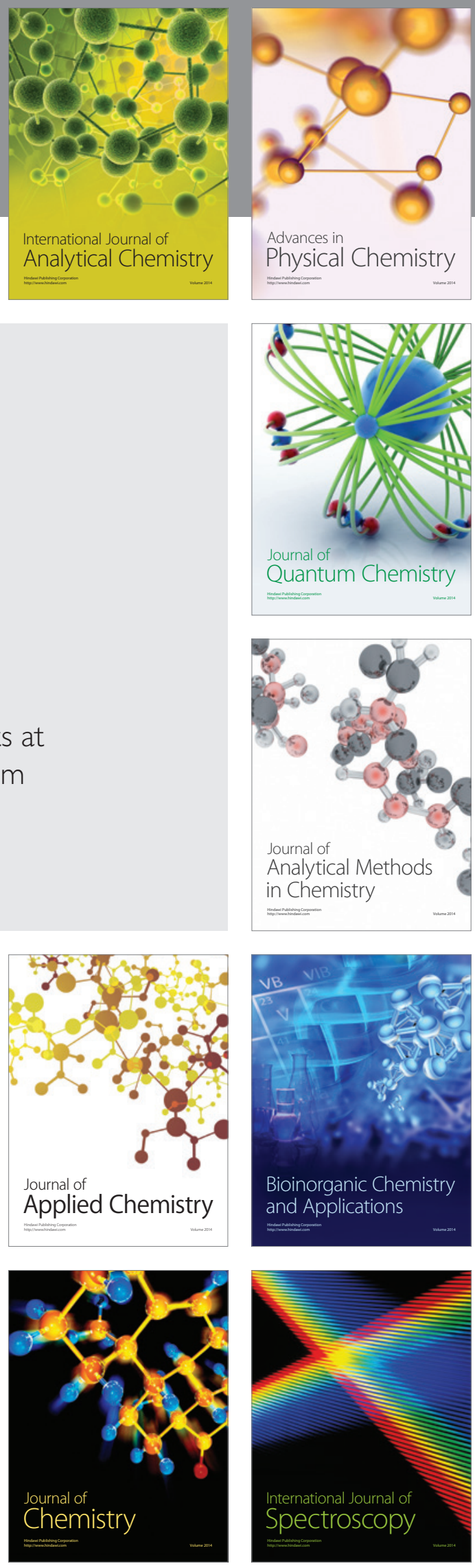